\title{
Gençlerin Siyaset Gündemi Konularına Yaklaşımı ve Medya Kullanım Alışkanlıklarının Belirlenmesi: 15 Temmuz Darbe Girişimi Örnek Olayı
}

\author{
DOI: $10.26466 /$ opus.359703
}

$*$

\author{
$\underline{\text { Yavuz Bayram }}^{*}$ \\ * Doç., Dr., Karadeniz Teknik Üniversitesi, İletişim Fakültesi, Trabzon/Türkiye \\ E-Posta: yavuzbayram@msn.com \\ ORCID: 0000-0002-1494-7823
}

Öz

Günümüz insanının siyasal gündeme ilişkin en önemli enformasyon kaynaklarım kitle iletişim araçları oluşturmaktadır. Özellikle siyasal ve sosyal kriz durumlarında kitle iletişim araçları kanaat oluşturmada hayati bir rol oynamaktadır. Teknoloji ile daha yakın ilişki içerisindeki genç nüfusun günümüzde haber medyasını takip etme ve siyasal gündemlerini oluşturma noktasında değişim ve dönüşüm gözlemlenmektedir. Yapılan bu çalışmada eğitimli gençlerin siyasal gündemlerini hangi kaynaklardan takip ederek oluşturduklarl, siyasal tutumların belirlemede hangi faktörlerin etkili olduğu, farklı medyaları ne sıklıkla takip ettikleri ve 15 Temmuz darbe sürecinde medyanın oynadığ rolü nasıl yorumladıkları sorularına cevap bulunmaya çalışılmıştır. Karadeniz Teknik Üniversitesi'nde lisans düzeyinde eğitim gören öğrencilerden seçilen örneklem grubuna anket çalışması uygulanmıştır. Çalışma sonucunda gençlerin gelenekselden çok internet tabanlı enformasyon kaynaklarından siyasal gündemi takip ettikleri, siyasal tutum geliştirme noktasında ise geleneksel enformasyon kaynakları ve birincil ilişkilerin geçerli olduğu ortamlara daha bağlı kaldıkları bilgisine ulaşılmıştır. Ayrıca gençlerin siyasal gündem konularına yüksek düzeyde ilgi gösterdikleri ve bu konuda kendilerini bilgili saydıkları da saptanmıştır. Üniversiteli gençlerin 15 Temmuz darbe sürecinde de medyanın rolünü önemsediği, fakat bu süreçte medyanın kendilerini yeterince bilgilendirmediğini düşündükleri sonuçlarına da ulaşılmıştır.

Anahtar Kelimeler: Siyaset gündemi, medya kullanımı, üniversite gençliği, 15 Temmuz darbe girişimi 
ISSN:2528-9527

E-ISSN:2528-9535

YIl Year:7

Cilt Volume:7

Sayı Issue: 13

Uluslararası Toplum Araştırmaları Dergisi

International Journal of Society Researches

Aralık December 2017

Makalenin Gelis Tarihi Received Date:30/11/2017

Makalenin Kabul Tarihi Accepted Date:11/12/2017

\title{
Approaching On The Issues Of Political Agenda And Identification Of Media Usage Habits Of The Youths: The Case Of The July 15 Coup Attempt
}

\begin{abstract}
Mass media are the most important sources of information regarding the political agenda of today's people. Especially in cases of political and social crisis, mass media plays a crucial role in constructing opinion. Today, young people in a closer relationship with technology are undergoing change and transformation at the point of following the news media and forming their political agendas. In this study, it was attempted to find answers to the questions about how educated young people follow their political agendas, what factors are influential in determining their political attitudes, how often they follow different media, and how they interpret the role played by the media during the July 15 coup. Questionnaires were applied to the sample group selected from the students who had undergraduate education at Karadeniz Technical University. As a result of the study, young people are more informed that they are following the political agenda from the internet based information sources rather than the traditional ones and that they are more dependent on traditional information sources and the environments where the primary relations are valid in terms of developing political attitudes. It has also been determined that young people have a high level of interest in the political agenda and that young people think they are knowledgeable in this regard. It was also found that college youngsters paid attention to the role of the media during the July 15 coup, but that they thought the media did not adequately inform themselves.
\end{abstract}

Key Words : Political agenda, media usage, university youth, The July 15 coup attempt 


\section{Giriş}

İletişim araştırmalarında medyanın önemli bir gündem belirleyici olduğuna dair önemli çalışmalar uzun zamandır yapılmaktadır. Medyanın özellikle bireylerin düşünce sınırlarının kalın çizgilerini çizerek, yani Bernard Cohen'in (1963'den aktaran McCombs, 1997, ss.10) ifadesiyle bireylerin ne düşüneceğinden çok ne hakkında düşünmesi gerektiğini ifade ederek gündelik yaşantı içerisinde önemli bir yer işgal ettiği gerçektir. Medya önemli bir gündem belirleyicisi olarak sıradan insanların yaşantısında etkili olduğu kadar karar alma noktasındaki siyasetçilerden bürokratlara kadar seçkin birey ya da gruplar üzerinde de etkili olmaktadır. Medyanın bu önemli rolünden hareket eden gündem belirleme çalışmaları zaman içerinde siyasetçinin, kamuoyunun ve medyanın gündemlerinin nasıl çalıştığını sistematize etme uğraşına girmiştir. 1960'lardan bu yana önce ABD'de sonra da Avrupa'da yapılan gündem belirleme çalışmaları Türkiye'yi de içerecek şekilde farklı ülkelerde gittikçe yaygınlaşarak yapılmıştır/yapılmaktadır.

Günümüzde bireylerin, özellikle de genç nüfusun medya kullanım alışkanlıklarında önemli değişiklikler gözlemlenmektedir ${ }^{1}$. Enformasyon alanında insanoğlunun yakaladığı ivme televizyon, gazete ve radyo gibi görsel ve işitsel kitle iletişim araçlarını ikinci plana itmektedir. Küreselleşme sürecinin önemli bir sonucu olarak ortaya çıkan tek tip yaşam tarzı

\footnotetext{
1 Örneğin Amerikan Gazeteler Birliği kuruluşu tarafından gençlerin medya kullanım alışkanlıkları üzerine 2010 yılında yaptırılan bir araştırma 2004 yılından 2009 yılına kadar olan dönemde ABD'de gençlerin medya kullanım alışkanlığında önemli değişiklikler olduğunu, gençlerin müzik ve ses, televizyon içeriği, bilgisayar ve bilgisayar oyunları gibi medya içeriklerini takip etmelerinde önemli artışlar olmasına rağmen sinema içeriğini takip etmelerinde bir değişim olmadığı, basılı medyayı takip etmelerinde ise düşüş olduğunu ortaya koymuştur. Araştırmaya göre gençlerin gazete okuma alışkanlığı 1999'da \%42 iken 2004'te \%34'e ve 2009'da \%23'e düşmüştür. (Kaynak: Valberg, Vivian, "Fitting into Their Lives, A Survey of Three Studies About Youth Media Usage", spring 2010, s.4, erişim adresi: https://www.americanpressinstitute.org/wp-content/uploads/2013/09/NIE_Fitting_into_their_lives.pdf, erişim tarihi: 07.10.2017). Uluslararası Bağımsız Araştırma Şirketi ıpsos KMG'nin 2012 yılında yapmış olduğu Gazete Okunurluk ve Algı Araştırması sonuçlarına göre de günlük haber, gelişmeler ve gündemi nereden takip ettikleri sorusuna katılımcıların verdiği cevaplar arasında ilk üç sırada televizyonların aldığı, sıralamada belirtilen ilk on beş marka içerisine, televizyon kanalları ve gazeteler dışında sosyal medya sitesi ve arama motoru ve bir internet sitesinin girdiği belirtilmiştir (Kaynak: 'Türk halkının \%53'ü gazete okuyor' başlıklı haber, erişim adresi: http://www.hurriyet.com.tr/turk-halkinin-yuzde-53-u-gazete-okuyor-22216611. Erişim tarihi: 07.10.2017).
} 
ve tüketim alışkanlıkları medya kullanım alışkanlıklarını da hızlı bir değişime uğratmıştır. Hızlı hayat döngüsü ve teknolojinin sundukları, enformasyon sağlayıcı mecraları da sanal âleme uyumlu hale getirmektedir. Böylece geleneksel medya kuruluşları hayatta kalabilme adına yeni düzene uyumlu hale gelmeye çalışırken gazetecilik meslek pratikleri de değişime uğramaktadır. Siyasal, sosyal ve ekonomik kriz durumlarında enformasyonu kontrol edebilecek mekanizmaların (sansürden haber havuzu uygulamaya kadar değişebilecek mekanizmalar) yetersiz kalması günümüz siyasal, sosyal, ekonomik ve askeri karar alıcılarının yaşadıkları önemli bir sorundur. Enformasyonun bu kadar akışkan olmasının yanında karar alma noktasındakiler tarafından kontrol edilememesi Türkiye'nin 15 Temmuz darbe girişimi tecrübesinde de kendini göstermiştir. Bu çalışmanın ana araştırma konusu da olan böylesine bir deneyim iletişim araştırmaları alanında önemli bir örnek olay olmaya adaydır. İşte yapılan çalışmada bu örnek olaydan hareket edilerek enformasyon sağlama noktasında değişen birey alışkanlıklarının önemli bir siyasal gündem konusu üzerinden nasıl okunması gerektiğine dair bir girişimdir. Çalışmada öncelikle öz bir şekilde bireylerin siyaset gündemi ve gündem belirleme yazını üzerinde durulduktan sonra araştırma tasarımı açıklanmıştır. Daha sonra ise elde edilen bulgular değerlendirilerek, ulaşılan sonuçlar ortaya konulmuştur.

\section{Gündem belirleme ve bireylerin siyasal gündemi}

İletişim çalışmaları açısından gündem, haber konusu olabilecek olayların önemine göre sıralanması şeklinde tanımlanabilir. Türkçe sözlükte gündem "meclis, kongre gibi toplantılarda görüşülecek konularn bütünü, ruzname" (TDK, 1998, s. 909) olarak açıklanmıştır. Yüksel, gündem kavramını " $z a-$ manın belirli bir noktasında önemlilik sırasına göre dizilmiş konular ve olaylar listesi biçiminde görülen stralama" (2001, s. 31), Dearing ve Rogers (1996, s. 2) ise zamanın herhangi bir anında önem sıralamasına göre bildirilen konular seti olarak tanımlamışlardır. Dearing ve Rogers, farklı konuların zaman içinde önemine göre yükselip düşerken, gündemin bu istikrarsızlığın bir enstantanesini sağladığını ifade etmişlerdir. 
Yukarıdaki tanımlamalardan da görüleceği üzere gündem kendi kendine oluşan bir şey olmayıp, birileri tarafından oluşturulmaktadır. Gündem birtakım insanlarca belirlenmekte ve ortaya 'gündem belirleme' diye bir olgu çıkmaktadır. Konu üzerine çalışan araştırmacılardan McQuail ve Windahl gündem belirleme kavramını, "kitle iletişim araçlarının bazı konulara ilgi duyarak ve bazıların da göz ardı ederek kamuoyu üzerinde etkide bulunması" (1997, s. 382) olarak, Mc Combs ve Shaw ise "bireylerin düşüncelerini biçimlendirmek için onların algısal yapısını etkileme yeteneği" olarak (Aktaran: Yüksel, 2001, s. 24) açıklamıştır. Dearing ve Rogers (1996, s. 1-2) ise gündem belirlemeyi medya profesyonellerinin, halkın ve politik seçkinlerin ilgisini kazanmayı amaçlayan konu destekçilerinin arasında süre giden bir rekabet olarak izah etmişlerdir. Şüphesiz gündem belirleme bir takım özel çabalar ile gerçekleşmektedir. Medya gündemi açısından medya profesyonellerinden siyasi kişiliklere kadar çeşitli faktörler medya gündemini belirleme noktasında etkili olabilmektedir. Aynı durum halkın ve siyasetin gündemini belirlerken de geçerlidir. Örneğin Başbakan veya Cumhurbaşkanı siyasetin gündemini belirlerken parlamento, medya, kanaat önderleri gibi faktörler de konunun doğasına göre siyaset gündeminin belirlenmesi noktasında etki gösterebilmektedir.

Gündem belirleme yazınında gündemin üç çeşidinden bahsedilmektedir (McCombs, 2005, s. 543-544) : medya gündemi, siyaset gündemi ve kamu gündemi. Bunlardan kamu gündemi ve kamu gündemi belirleme literatürü McCombs ve Shaw'ın 1972 yılında yayınladıkları ‘Kitlesel Medyanın Gündem Belirleme Fonksiyonu' isimli makalelerine dayanmaktadır. Kamu gündemi isminden de anlaşılacağı üzere kamunun, yani halkın gündemindeki sorun, konu ve olayların öncelik sıralamasıdır. Kamu gündemi belirleme ise kitlesel medya içeriğinde resmedilen sorunlar ile kamunun öncelikli sorunları arasındaki bağı ele almaktadır. Siyaset gündemi ise siyasal alandaki konu, olay ve sorunların öncelik sıralaması olup, siyaset gündemi belirleme çalışmaları ise seçilmiş devlet görevlilerinin kamu gündemi ile bağlantılı gündemlerine ve yasa yapma alanındaki sorun gündemine odaklanmakta ve bunların medya gündemi ile ilgisi üzerinde durmaktadır. Siyasal gündem 'politik aktörlerin dikkatlerini odakladıkları sorunların listesi' (Walgrave, Soroka\&Nuytemans, 2008, s. 815) olarak tanımlanabilir. McCombs siyasal gündemi herhangi bir zaman di- 
liminde mevcut politik sistem içerisinde karar alma ve tartışma sorunlarına ilişkin konular seti olarak tarif etmiştir (1981, s. 288). Siyasal gündemin nasıl oluştuğu konusu bilim insanlarınca araştırılmış, birçok sorun seti varken belli konuların nasıl siyasal gündeme geldiği yani yükseldiği, nasıl bir çok sorunun siyasal gündemden düştüğü açıklanmak istenmiştir. Atabek'e göre (1998, s. 168) bir sorunun medya ve kamu gündeminden geçerek siyasal gündeme oturması kısaca bir takım aşamalardan geçerek gerçekleşir. Öncelikle haber konusu olabilecek sorun kitle iletişim araçlarında yer alır. Böylece soruna ilişkin yapılan haberlerle sorunun izleyici için önemliliği belirlenmiş olur. Bireylerin gündeminde sorunun önem s1rasının artması, bireysel kanaatlerin toplamından oluşan kamuoyunda da sorunun daha çok tartışılmasını sağlar. Böylece kamu gündeminde önemi artan sorunun politik yapıcıların tercihlerini etkileyeceği varsayılır.

Üçüncü gündem türü olan medya gündemi ise medyada yer alan olay/konu ve sorunların önem sıralanmasının nasıl oluştuğu, vurgulandığı ile ilgilenmektedir (Kosicki,1993, s. 100). Gündem türleri üzerine daha farklı sınıflamalardan da bahsedilebilir. Örneğin Inga Huck vd. makalelerinde beş farklı gündem tipi belirlemişlerdir. Bunlar; 'gerçek medya gündemi', ‘bireysel olarak algılanan medya gündemi', 'bireysel olarak algılanan kamu gündemi', 'bireyin kişisel gündemi' ve 'çok yaygın olarak kullanılan kamu gündemi'dir. (2009, s. 141). Literatürde ise yaygın olarak kamu, siyaset ve medya gündemi sinıflandırması kullanılmaktadır. Her üç gündem türü aslında birbirinden bağımsız değildir. Rogers ve Dearing (1988, s. 555-594) gündem belirleme alanında yapmış oldukları çalışmalarda bu üç gündem türünün birbiri ile bağlantılı şekilde işlediğini ifade etmişlerdir.

J. B. Manheim Gündem Dinamikleri Modeli isimli eserinde medyakamu ve siyasal gündemin etkileşimi içerisinde gündem oluşturmanın ortaya çıktığını ifade ettikten sonra bu üç gündem türünün şu üç boyutu içerecek biçimde kavramsallaştırıldığın ifade etmiştir (Aktaran: Severin ve Tankard, 1994, s. 397-398); İlk olarak medya gündemi için bu boyutların görünürlük (konuya verilen kapsamın büyüklüğü), izleyici önemliliği (haber kapsamının izleyici gereksinimleriyle olan ilgisi) ve değerlik (konu lehine ve aleyhine ayrılan medya kapsamı) olduğunu ifade etmiştir. İkinci olarak siyasal gündem için bu boyutların destek (konuya verilen az ya da çok lehinde eylem), eylemin olma olasılığı (bir resmi kuruluşun konu için 
eyleme geçme olasılığı) ve eylem özgürlüğü (olası hükümet eyleminin boyutu) olduğunu belirtmiştir. Son olarak kamu gündemi için bu boyutları bilinilirlik (konudan kamunun haberdar olma düzeyi), kişisel önemlilik (kişinin kendisinde gördüğü konuya ilişkin ilgi), lehtelik (konu üzerinde lehte ve aleyhte yargılar) olarak ortaya koymuştur. Yapılan bu çalışmada da Manheim'in kamu gündemi belirleme çalışmalarında kullanılan boyutlardan faydalanılmıştır. Uygulanan anket çalışması ile katılımcıların seçilen örnek olaya ilişkin öncelikle olaydan haberdar olma düzeyleri belirlenmiş, daha sonra hem örnek olaya ilişkin hem de kendi kişisel ajandalarına ilişkin ilgi bulgulanmaya çalışılmıştır. Son olarak da seçilen örnek olayda medyanın kamu gündemini oluşturmada ki rolünü ortaya çıkarabilmek adına katılımciların ankette yer alan önermelerin lehinde ya da aleyhinde olup olmadıklarına bakılmıştır.

\section{Çalışmanın Amacı ve Önemi}

Gündem belirleme yazınında genellikle medya, siyaset ve kamu gündeminin oluşmasında kitle iletişim araçlarının ve başka bazı faktörlerin (ABD Başkanı, sivil toplum örgütleri, yüksek yargı organları gibi) ne derecede etkili olduğunun araştırıldığ 1 görülmektedir². Özellikle medya ve kamu gündemine ilişkin yapılan çalışmaların siyaset gündemine ilişkin (siyasetçilerin ya da yasama mensuplarının gerçek gündemlerini belirleyen faktörleri ölçümlemenin zorluğundan dolayı) yapılan çalışmalara k1yasla daha fazla olduğunu söylemek mümkündür. Yine gerçek dünya göstergelerinin (enflasyon, işsizlik, terör vb.) medya gündemine nasıl yerleştiğine dair yapılan çok sayıda çalışma da mevcuttur.

\footnotetext{
${ }^{2}$ Bknz. Funkhouser, G (1973). "The issues of the sixties: An exploratory study in the dynamics of public opinion". Public Opinion Quarterly. 37 (1): 62-75, Takeshita T., "Agenda Setting Effects of the Press in a Japanese Local Election", Studies of Broadcasting, 1993, pp. 194-216., Weaver, D. H., Mccombs, M. E., \& Spellman, C. (1975). Watergate and the Media: A Case Study of Agenda-Setting. American Politics Quarterly, 3, 458-472., Wanta Wayne-Foote Joe, "The President-News Media Relationship: A Time Series Analysis of Agenda Setting", Journal of Broadcasting and Elevtronic Media, 38, 1994 pp.437-448. Irvan Süleyman, Dış Politika ve Basın: Türk Basınındaki Dış Politika Haberlerinin Gündem Belirleme Yaklaşımı Açısından Çözümlenmesi, Yayınlanmamış Doktora Tezi, Ankara Üniversitesi Sosyal Bilimler Enstitüsü, 1997. Yüksel Erhan, Türkiye'de Ekonomi Basını Gündemi ve Siyasal Gündem Ilişkisi: Özelleştirme Örneğinde Bir Gündem Belirleme Çalışması, Anadolu Üniversitesi Sosyal Bilimler Enstitüsü, Yayınlanmamış doktora Tezi, 1999.
} 
Türkiye'de bireylerin siyasal gündeminin nasıl oluştuğuna dair yap1lan çalışma sayısı fazla değildir. Literatüre bakıldığında Balcı ve arkadaşları 2016 yılında yapmış oldukları bir çalışmada siyasal bilgilenmede medyanın oynadığı rolü üniversite gençliği örneğinden hareketle incelemişlerdir. Arklan ve Karakoç (2015) ise yapmış oldukları çalışmada üniversite gençliğinin genel ve siyasal gündeme ilişkin haber kaynaklarını ortaya koymuşlardır. Başka bazı çalışmalar ise üniversite öğrencilerinin medya kullanım alışkanlıklarını kullanımlar ve doyumlar yaklaşımı çerçevesinde araştırmıştır. Bu çerçevede yapılan çok sayıdaki çalışmadan örneğin Küçükkurt vd. (2009) çeşitli üniversitelerde gerçekleştirmiş oldukları anketler aracılığı ile öğrencilerin medya kullanım alışkanlıklarının arkasında yatan faktörleri ortaya koymaya çalışmışlardır. Toruk ise (2008) üniversite gençliğinin medya kullanım alışkanlıklarını kullanımlar ve doyumlar yaklaşımı çerçevesinde analiz etmiştir. Yapılan bu çalışmada ise gündem belirleme kuramından hareketle seçilen örnek bir siyasal gündem konusunun üniversite öğrencilerinin kişisel siyaset gündemlerine nasıl yerleştiği, bu yerleşmede kitle iletişim araçlarının ne ölçüde rol oynadığı değişen medya kullanım alışkanlıkları çerçevesinde açıklanmaya çalışılmıştır. $\mathrm{Bu}$ anlamda yapılan çalışma yakın örneklerinden bir ölçüde farklılık arz etmektedir.

Çalışma için seçilen kriz durumu olarak 15 Temmuz darbe girişiminin topyekûn tüm ülke insanının siyasal ajandasını etkilemesi sebebiyle iyi bir örnek oluşturacağı düşünülmüştür. Ayrıca bu tür kriz durumları insanların siyasal belleğinde önemli izler bırakmakta olup, bilimsel bir araştırma için önemli donelere ortaya koyabilmektedir. Literatüre bakıldığında ise Türkiye'de 15 Temmuz darbe girişimi merkezli -ki bu çalışmanın merkezini oluşturmamaktadır - bazı akademik çalışmaların yanında, bu kriz durumunu örnek olay olarak kullanan az sayıda çalışmanın yapıldığı görülmüştür. Darbe sürecini çalışmasının merkezine alan Haluk Alkan (2016) '15 Temmuzu Anlamak, Parametreler ve Sonuçlar' isimli makalesinde süreci askeri-siyasal pencereden açılamak istemiştir. Devran ve Özcan (2016) ise '15 Temmuz Darbe Girişimi: Gelenekselden Yeniye Medya Araçlarının Kullanımı' isimli çalışmalarında ise darbe sürecinde medyanın oynadığı rolü teorik bir takım tespitler ile örneklendirerek açıklama yoluna gitmişlerdir. Melek ve Toker (2017) ise 'Şiddet, Demokrasi ve Terör Bağlamında Ana Akım Medyanın Analizi: 15 Temmuz Darbe Girişimi' 
başlıklı çalışmalarında ana akım medyada yer alan ilgili haberlere içerik analizi uygulayarak, darbe girişiminin haberlerde nasıl temsil edildiğini bulgulamışlardır. Söz konusu çalışmalar dışında akademik düzeyde çalışma yapılmamış olması ve darbe girişimi ile bağlantılı olarak gençlerin medya kullanım alışkanlıklarındaki değişimin ve siyaset gündemlerinin nasıl oluştuğunun sorgulanması çalışmayı alana katkı yapar hale getirmektedir.

\section{Çalışma Grubu}

Çalışma evreni olarak üniversite gençliği, örneklem olarak da Karadeniz Teknik Üniversitesi (KTÜ)'nde lisans düzeyinde eğitim gören tüm öğrenciler seçilmiştir. Yüzde 95 güven aralığında lisans düzeyinde eğitim gören 36.668 öğrenciden en az 381 öğrenci ile anket uygulanması gerekliliği karşısında 558 öğrenci ile anket çalışması gerçekleştirilmiştir. Anket formlarının $119^{\prime} \mathrm{u}$ birden fazla şıkkın işaretlenmesi ya da bazı maddelerin tamamen boş bırakılması gibi nedenlerden dolayı değerlendirme dışına çıkarılmış, 439 anket çalışması ise çalışmaya dahil edilmiştir. KTÜ'den alınan güncel verilere göre üniversitenin lisans düzeyinde programlara kayıtlı toplam 36.668 öğrencisi vardır. Çalışma örneklemine lisans düzeyinde eğitim gören tüm öğrenciler dahil edilmesine rağmen, çalışmanın sınırlılıkları düşünüldüğünde her fakülteden fakülte öğrenci sayısının genel öğrenci sayısı içerisindeki ağırlığı oranında temsilen bir grup öğrenci ile anket yapılması homojen dağılım için uygun görülmüştür. Buna göre fakültelerin her birinin öğrenci sayıları saptanarak lisans eğitimi gören toplam öğrenci sayılarına oranlamaları yapılmış ve bu şekilde her fakülteden kaç öğrenci ile anket yapılacağına dair bir sonuca ulaşılmıştır.

\section{Yöntem}

1-30 Aralık 2016 tarihleri arasında gerçekleştirilen anket uygulamasında öğrencilere yaş, cinsiyet ve hangi fakültede okudukları, darbe girişimi s1rasında hangi ilde oldukları sorularak katılımcıların homojenliği hakkında bilgi edinilmek istenmiştir. Bu sorular dışında anket çalışması dört kısma ayrılabilecek biri açık uçlu toplam 16 sorudan oluşturulmuştur. Katılımcıların medyayı ve gündemi takip etme alışkanlıklarını belirlemek 
için 'her gün, haftada birkaç gün, haftada bir gün, nadiren ve hiç' tercihlerini içeren, seçilen örnek olaya ilişkin katılımcıların tutumlarını belirlemeye yönelik sorularda ise 'tamamen katılıyorum, birçok yönden katılıyorum, ne katılıyorum ne de katılmıyorum, kısmen katılıyorum ve hiç katılmıyorum' tercihlerini içeren beşli likert ölçeği kullanılmıştır. Katılımcıların siyasal gündemlerinin kaynakları ise çoktan seçmeli sorularla ölçülmüştür. Anket verileri SPSS 21 paket programında betimleyici analiz tekniklerinden frekans analizi ile değerlendirilerek yorumlanmıştır. Katılımcıların kişisel siyasal gündemlerine ve medya kullanım alışkanlıklarına ilişkin verilerin anket tekniği ile uygulandığı dönemde elde edilmesi bu çalışmanın en önemli sınırlılıklarını oluşturmaktadır. Frekans sayımına dayalı bir yöntem ile özellikle algıya yönelik tespitler yapılması önemli olmakla birlikte, bir takım nitel tekniklerin uygulanmayışı da çalışmanın en önemli sınırlılığıdır. Çalışmaya ilişkin temel hipotezler şunlardır:

H1: Günümüzde üniversiteli gençler siyaset gündemini yakından takip etmektedir.

H2: Üniversiteli gençler siyasal gündemi geleneksel medyalardan ziyade yeni medya teknolojileri üzerinden takip etmektedir.

H3: Üniversiteli gençler siyasal gündemi geleneksel medyaların daha güvenilir yansıttığını düşünmektedir.

H4: Üniversiteli gençlerin bir siyasal tutum ve düşünce geliştirmelerinde doğrudan iletişimin egemen olduğu birincil ilişki grupları (arkadaş, aile, sivil toplum vb.) iletişimin dolaylı geliştiği kitle iletişim araçlarına göre daha belirleyici olmaktadır.

Yukarıdaki hipotezleri sınamak üzere anket formunda katılımcılara siyasal gündeme ilişkin tutum ve davranışlarını ölçme amacındaki dört soru sorulmuştur. H1'i sinamak üzere 'siyasal gündemi takip etme sıklıkları', H 2'yi sinamak üzere 'siyasal gündemi takip etmek için en çok kullandıkları haber kaynağı' ile 'gazete ve televizyonları okuma ve izleme sıklıkları' ve 'haber portallarını takip etme sıklıkları' sorulmuştur. H3'ü sınamak üzere de 'siyasal gündemi en güvenilir olarak yansıttığını düşündükleri kitle iletişim aracının ne olduğu' sorulmuştur. $\mathrm{H} 4$ ise katılımcılara 'bir siyasal tutum veya düşünce geliştirmenizde üzerinizde en çok etkili olan faktör nedir?' sorusu sorularak sınanmıştır. 
H5: Günümüzde üniversite gençliği sosyal medyayı aktif olarak kullanmakta ve sıklıkla sosyal medyadan paylaşım yapmaktadırlar.

H6: 15 Temmuz darbe girişimi sırasında üniversiteli gençler sosyal medyayı paylaşımda bulunarak aktif bir şekilde kullanmıştır.

Yukarıdaki hipotezleri sınamak üzere üç soru oluşturulmuştur. Bu sorularda katılımcılara 'sosyal medyayı kullanma sıklıkları', 'sosyal medyada paylaşımda bulunma sıklıkları' ve 'siyasal gündem konusu olarak ele alınan 15 Temmuz darbe girişimi sonrasında katılımcıların 'sosyal medyadan paylaşımda bulunup bulunmadıkları', sorulmuştur. Böylece katılımcıların önemli bir siyasal gündem konusu oluştuğunda sosyal medyayı ne ölçüde kullandıkları ölçümlenmek istenmiştir.

H7: Siyasal gündeme ilişkin kriz durumunda üniversiteli gençler medyadan ve sosyal çevrelerinden gelen enformasyona aktif şekilde ilgi göstermektedir.

H8: Üniversite gençliği kriz durumuna ilişkin medyanın halkı yeteri kadar bilgilendirdiği, dolayısıyla darbe girişiminin önlenmesinde medyanın önemli bir rolü olduğunu düşünmektedir.

H 7 ve H 8 siyasal gündemi meşgul eden kriz durumuna ilişkin katılımcların ilgi düzeyini ve medyanın kriz durumunda oynadığı role ilişkin algılarını sınama amacındadır. Bu amaçla katılımcılara 'darbe girişimi sonrasında medya veya sosyal çevrelerinden yayılan bilgilere ilgi gösterme düzeyleri' sorulmuş, daha sonra ise 'darbe girişimi gerçekleştikten sonra medyanın toplumu konuya ilişkin yeteri kadar bilgilendirdiği önermesine katılıp katılmadıkları' ile 'darbe girişiminin önlenmesinde medyanın önemli bir rol oynadığına dair önermeye katılıp katılmadıkları' sorulmuştur. Ayrica '15 Temmuz darbe girişimi ve medya denildiği zaman aklınıza ilk gelenleri bir iki kelime ile ifade ediniz' açık uçlu sorusu ile de medyanın katılımcıların zihninde kriz durumuna ilişkin yarattığı imgeler hakkında ipuçları elde edilmek istenmiştir.

\section{Bulgular}


Tablo 1'de katılımcıların yaş dağılımına bakıldığında 439 kişinin en çok 246 (\% 56) kişi ile 20-22, yaş aralığında olduğu görülmüştür. Katılımcıların 220 'sini $(\% 50,1)$ erkekler, 216'sını $(\% 49,2)$ kadınlar temsil edilmiştir. Cinsiyet açısından katılımcıların homojen dağılımı söz konusudur.

Tablo 1. Ankete katılanların yaş ve cinsiyet dağılımları

\begin{tabular}{llllll}
\hline Yaş aralıkları & $\mathrm{N}$ & $\%$ & Cinsiyet grupları & $\mathrm{N}$ & $\%$ \\
\hline $17-19$ & 85 & 19,4 & Kadın & 216 & 49,2 \\
$20-22$ & 246 & 56 & Erkek & 220 & 50,1 \\
$23-25$ & 88 & 20 & Diğer & 3 & 0,7 \\
$26-28$ & 14 & 3,2 & & & \\
29 ve üstü & 6 & 1,4 & & 439 & 100,0 \\
\hline Toplam & 439 & 100,0 & Toplam & & \\
\hline
\end{tabular}

Tablo 2. Ankete katılanların fakültelere göre dă̆ılımı

\begin{tabular}{lll}
\hline Fakülteler & $\mathbf{N}$ & $\mathbf{\%}$ \\
Mühendislik & 90 & 20,5 \\
Tip & 16 & 3,6 \\
Orman & 16 & 3,6 \\
Deniz Bilimleri & 9 & 2,1 \\
\hline Iletişim & 12 & 2,7 \\
Eğitim & 63 & 14,4 \\
Eczacllık & 6 & 1,4 \\
İlahiyat & 14 & 3,2 \\
Edebiyat & 31 & 7,1 \\
Fen & 18 & 4,1 \\
İ.̇.B.F & 112 & 25,5 \\
Mimarlık & 12 & 2,7 \\
Sağllk bilimleri & 12 & 2,7 \\
Of Teknoloji & 12 & 2,7 \\
Hukuk & 16 & 3,6 \\
Toplam & 439 & 100,0 \\
\hline
\end{tabular}

Tablo 2'de görüleceği üzere lisans programlarına kayıtlı toplam öğrenci sayısı içerisinde 10.098 öğrenci ile en çok temsil edilen İktisadi ve İdari Bilimler Fakültesi (İ.İ.B.F) öğrencilerinden 112 si ile (katılımcıların \%25,5'i) anket çalışması gerçekleştirilmiştir. Sayı bakımında ikinci en kalabalık fakülte olan Mühendislik Fakültesinden ise 90, öğrenci sayısı bakımından 
üçüncü sırada ki Eğitim Fakültesi'nden 63 öğrenci ile anket çalışması gerçekleştirilmiştir. Ankete katılanların 15 Temmuz darbe girişimi sırasında hangi şehirde bulunduklarına ilişkin veriler de toplanmıştır. Bu sayede katılımcların Türkiye genelini ne kadar temsil ettikleri öğrenilmek istenmiştir. Katılımcıların 201'i (\% 45,8) darbe girişimi sırasında en çok Karadeniz bölgesinde ve 107 kişi ile Trabzon ilinde bulunduklarını ifade etmişlerdir. İkinci sırada ise en çok Marmara bölgesinde (katılımcıların 101) ve 60 kişi ile İstanbul ilinde bulunduklarını, üçüncü sırada ise en çok İç Anadolu bölgesi (49 kişi) ve 22 kişi ile Ankara şehrinde olduklarını söylemişlerdir. Karadeniz bölgesi dışındaki katılımcıların büyük bir bölümünün İstanbul, Ankara ve İzmir gibi büyük şehirlerden gelen öğrenciler olması (toplam 93 kişi) katılımcıların kısmen homojen dağılımının bir diğer göstergesi olmuştur.

Çalışma kapsamında katılımcılara sosyal medyayı ne sıklıkla kullandıkları sorulmuştur (Tablo 3). Katılımcıların 366'sının sosyal medyayı her gün kullandıkları görülmüştür. Nadiren ya da hiç kullanmıyorum diyenler ise toplamda 39 kişidir.

Tablo 3. Katılımcıların sosyal medya kullanım alışkanlıklarına ilişkin veriler

\begin{tabular}{lllllll}
\hline $\begin{array}{l}\text { Sosyal Medyayı Kul- } \\
\text { lanma Sıklığı }\end{array}$ & $\mathrm{N}$ & $\%$ & $\begin{array}{l}\text { Sosyal medyada } \\
\text { paylaşımda bu- }\end{array}$ & $\mathrm{N}$ & $\%$ \\
\hline Her gün & 366 & 83,4 & Çok sık & 24 & 5,5 \\
Haftada birkaç defa & 33 & 7,5 & Sıklıkla & 75 & 17,1 \\
Haftada bir defa & 1 & 0,2 & Bazen & 182 & 41,5 \\
Nadiren & 26 & 5,9 & Nadiren & 110 & 25,1 \\
Hiç & 13 & 3 & Hiç & 48 & 10,9 \\
Toplam & 439 & 100 & Toplam & 439 & 100 \\
\hline
\end{tabular}

Buradan hareketle üniversite öğrencilerinin çok büyük bir kısmının sosyal medyayı her gün kullandıklarını söylemek doğru olur. Sosyal medya uygulamalarını sadece bir şeyleri okumak veya izlemek amaciyla kullanan insanlar olduğu gibi aktif olarak sosyal medya uygulamalarında paylaşımda bulunan, video veya fotoğraf yükleyen insanlar da vardır. Yapılan çalışmada öğrencilerin paylaşımda bulunma sıklığı üzerinden sosyal medyayı ne kadar aktif olarak kullandıkları da saptanmaya çalışılmıştır. Buna göre 182 öğrenci sosyal medyada bazen, 75 öğrenci sıklıkla ve 24 
öğrenci ise çok sık paylaşımda bulunduklarını belirtmişlerdir. Yani öğrencilerin toplamda yüzde 64,1'lik kısmı sosyal medyada çeşitli derecelerde paylaşımda bulunduklarını belirtmişlerdir. Darbe girişimi sırasında ve sonrasında sosyal medyadan herhangi bir paylaşımda bulunup bulunmadıkları da katılımcılara sorulmuştur. Böylece bir kriz durumunda öğrencilerin sosyal medyayı aktif olarak kullanıp kullanmadıkları öğrenilmek istenmiştir. Buna göre 280 katılımcı (\% 63,8) herhangi bir paylaşımda bulunmadıklarını, 159 katılımcı ise bulunduklarını ifade etmiştir. Sonuç olarak üniversiteli gençlerin sosyal medyayı kullanma ve paylaşımda bulunma aktifliği seçilen örnek olayda işlememiştir. Gençlerin sosyal medyayı aktif kullandığı ve buradan paylaşımda bulunduklarını savlayan $H$ 5 kanıtlanmış fakat darbe girişimi sırasında gençlerin sosyal medyayı aktif kullandığı varsayımına dayalı H 6 kanıtlanamamıştır.

Tablo 4. Katılımcıların haber medyası kullanma alışkanlıklarına ilişkin veriler

\begin{tabular}{|c|c|c|c|c|c|c|c|c|}
\hline $\begin{array}{l}\text { Gazete } \\
\text { okuma } \\
\text { sıklığ1 }\end{array}$ & $\mathrm{N}$ & $\%$ & $\begin{array}{l}\text { Televizyon } \\
\text { izleme sık- } \\
\text { liğı }\end{array}$ & $\mathrm{N}$ & $\%$ & $\begin{array}{l}\text { Haber portal- } \\
\text { larını takip } \\
\text { etme sıklığı }\end{array}$ & $\mathrm{N}$ & $\%$ \\
\hline Her gün & 55 & 12,5 & Her gün & 70 & 15,9 & Her gün & 185 & 42,1 \\
\hline $\begin{array}{l}\text { Haftada } \\
\text { birkaç } \\
\text { gün }\end{array}$ & 90 & 20,5 & $\begin{array}{l}\text { Haftada } \\
\text { birkaç gün }\end{array}$ & 119 & 27,1 & $\begin{array}{l}\text { Haftada birkaç } \\
\text { gün }\end{array}$ & 128 & 29,2 \\
\hline $\begin{array}{l}\text { Haftada } \\
\text { bir gün }\end{array}$ & 33 & 7,5 & $\begin{array}{l}\text { Haftada bir } \\
\text { gün }\end{array}$ & 35 & 8 & $\begin{array}{l}\text { Haftada bir } \\
\text { gün }\end{array}$ & 35 & 8 \\
\hline Nadiren & 194 & 44,2 & Nadiren & 138 & 31,4 & Nadiren & 73 & 16,6 \\
\hline Hiç & 67 & 15,3 & Hiç & 77 & 17,5 & Hiç & 18 & 4,1 \\
\hline Toplam & 439 & 100 & Toplam & 439 & 100 & Toplam & 439 & 100 \\
\hline
\end{tabular}

Tablo 4'te haberlerin yayıldığı geleneksel kitle iletişim araçları ile internetin ortaya çıkardığı yeni habercilik ortamlarını gençlerin ne oranda kullandıklarına ilişkin veriler bulunmaktadır. En eski haber araçlarından olan gazetelere gençlerin ilgisinin düşük olduğu saptanmıştır. Buna göre ankete katılan gençlerin yüzde 59,5'lik gibi önemli bir kısmı gazeteleri ya nadiren okuduklarını ya da hiç okumadıklarını belirtmişlerdir. Televizyonlar açısından durum biraz daha iyi olmakla birlikte yine de katılımc1ların neredeyse yarıya yakını (yüzde 48,9 ) televizyonları ya hiç izlemediklerini ya da nadiren izlediklerini belirtmişlerdir. Böylece $\mathrm{H}$ 2'nin gençlerin 
geleneksel medyadan gündemi takip etmediklerine dair kısmı doğrulanmıştır. Tablo 4'te de görüleceği üzere katılımciların büyük bir kısmının (yüzde 71,3) haber portallarını her gün ya da haftada birkaç gün takip ettikleri bulunmuştur. Böylece $\mathrm{H}$ 2'nin üniversiteli gençlerin gündemi yeni medya teknolojilerinden takip ettiği varsayımı kanıtlanmıştır.

Yapılan çalışmada katılımcıların siyaset gündemini ne sıklıkla takip ettikleri ve siyaset gündemine ilişkin bilgilerinin düzeyini nasıl gördükleri de ölçülmek istenmiştir. Tablo 5'den de görüleceği üzere öğrencilerin önemli bir kısmının siyaset gündemini toplamda yüzde 52,4'lük bir oranla 'çok sık' ve 'sıklıkla' takip ettikleri, yüzde 31'lik kısmının da 'bazen takip ederim' seçeneğini işaretleyerek siyaset gündemine en azından kayıtsız kalmadıkları sonucuna ulaşılmıştır. Ankete katılanlara Türkiye'nin siyasal gündemine ilişkin sahip oldukları bilgilerini ne düzeyde gördükleri de sorulmuştur. Buna göre katılımcılar sırasıyla en çok 'orta' (yüzde 46,2), 'yüksek' (yüzde 33) ve 'çok yüksek' (yüzde 10,7) şıklarını işaretleyerek Türkiye'nin siyasal gündemine ilişkin bilgilerinin düzeyini öncelikle 'orta' sonra da 'yüksek ve çok yüksek' olarak gördüklerini ifade etmişlerdir. Böylece H 1 kısmen kanıtlanmıştır. Üniversite gençliği siyaset gündemini yakından takip etmekle birlikte, bu gündeme ilişkin bilgilerini daha çok orta düzey olarak gördüklerini ifade etmişlerdir.

Tablo 5. Katılımcıların kişisel-siyasal gündemlerine ilişkin veriler

\begin{tabular}{lllllll}
\hline $\begin{array}{l}\text { Siyaset Günde- } \\
\text { mini } \begin{array}{c}\text { Takip } \\
\text { Etme Sıklığı }\end{array}\end{array}$ & $\mathrm{N}$ & $\%$ & $\begin{array}{l}\text { Siyaset } \\
\text { Hakkında Bündemi } \\
\text { hibi Olma Düzeyi }\end{array}$ & $\mathrm{Na}$ & $\%$ \\
\hline Çok sık & 82 & 18,7 & Çok yüksek & 47 & 10,7 \\
Sıklıkla & 148 & 33,7 & Yüksek & 145 & 33,0 \\
Bazen & 136 & 31,0 & Orta & 203 & 46,2 \\
Nadiren & 55 & 12,5 & Düşük & 42 & 9,6 \\
Hiç & 18 & 4,1 & Hiç & 2 & 0,5 \\
Toplam & 439 & 100 & Toplam & 439 & 100 \\
\hline
\end{tabular}

Yapılan çalışmada öğrencilerin siyasal gündemi takip etmek için kullandıkları kitle iletişim araçları da sorgulanmıştır. Tablo 6' da da görüleceği üzere üniversite öğrencilerinin siyasal gündeme ilişkin gelişmeleri daha çok yeni medya olarak adlandırılan internet tabanlı medya kaynaklarından takip ettikleri ortaya çıkmıştır. H 2'de savlandığı gibi üniversite 
gençlerinin ülkenin siyasal gündemini yüzde 72,4 oranında yeni medya ortam ve uygulamalarından takip ettikleri bulgulanmıştır. Ankette öğrencilerin siyasal gündemi takip etmek için kullandıklara kaynaklara ne düzeyde güvendikleri de araştırılmıştır. H 3'de öne sürüldüğü gibi katılımcıların geleneksel medyayı sosyal medyaya göre siyasal gündemi yansıtma konusunda daha güvenilir bulmaları beklenmiştir. Tablo $6^{\prime}$ dan da görüleceği üzere bu varsayım kısmen doğrulanmıştır. Katılımcıların yüzde 47,5'i televizyon, gazete ve radyo gibi geleneksel medyaların gündemi daha güvenilir yansıttığına (ki televizyonların görüntü eşliğinde haber vermesi ve canlı yayın yapmasının güvenilirliğini arttırdığı düşünülmektedir) inanmıştır. İnternet tabanlı uygulamalardan haber portalları da siyaset gündemini güvenilir yansıtmada ikinci sırada yer almıştır.

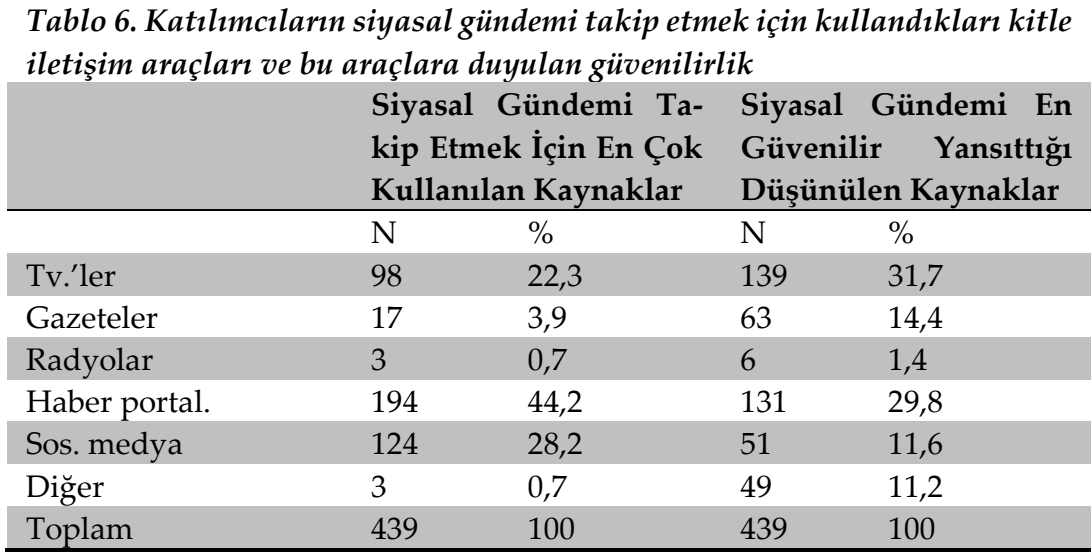

Tabloda 7'de de görüldüğü üzere üniversite gençlerinin bir siyasal tutum geliştirmelerinden üzerlerinde en çok etkili olan faktör geleneksel kitle iletişim araçlarıdır. Buna göre katılımcılar bir siyasal tutum geliştirmelerinde üzerlerinde en çok televizyon/radyo vb. görsel-işitsel kitle iletişim araçları ile gazete/dergi vb. basılı kitle iletişim araçlarının (toplam \% $48,7)$ etkili olduğunu ifade etmişlerdir. Üniversiteli gençlerin bir siyasal tutum ve düşünce geliştirmelerinde doğrudan iletişimin egemen olduğu birincil ilişki grupları $\mathrm{H}$ 4'de beklenilenin aksine etkili olamamıştır. Katılımcların ülke siyasal gündemini internet tabanlı medyadan (Tablo 6) 
daha çok takip etmesi gerçeğine karşın, tutum geliştirme noktasında geleneksel kitle iletişim araçları daha etkili olmuştur.

Tablo 7. Katılımcıların siyasal tutum geliştirmelerinde etkili olan faktörler

\begin{tabular}{lll}
\hline & $\mathbf{N}$ & $\mathbf{\%}$ \\
Televizyon/radyo vb. görsel-işitsel kitle iletişim araçları & 119 & 27,1 \\
Gazete/dergi vb. basılı kitle iletişim araçları & 95 & 21,6 \\
Aile ve arkadaş grupları & 70 & 15,9 \\
İnternet ve sosyal medya & 70 & 15,9 \\
Sivil toplum, siyasal partiler, gönüllü kuruluşlar & 54 & 12,3 \\
Diğer & 31 & 7,1 \\
Toplam & $\mathbf{4 3 9}$ & $\mathbf{1 0 0}$ \\
\hline
\end{tabular}

$\mathrm{Bu}$ durumun altında internet tabanlı uygulamalarda haberin kolayca manipülasyona uğraması karşısında televizyonlar ve gazeteler gibi geleneksel kitle iletişim araçlarında bunun zor olması ve yasalar önünde hesap verebilirlik açısından geleneksel kitle iletişim araçlarının daha kurumsallaşmış olduğu gerçeğinin yattığı düşünülmektedir. Özetle katılımcılar siyasal tutum geliştirme noktasında kitle iletişim araçlarını, yüz yüze iletişimin geçerli olduğu ortamlara göre daha fazla önemsemektedir.

Tablo 8. Örnek kriz durumuna ilişkin veriler

\begin{tabular}{|c|c|c|c|c|c|c|c|c|}
\hline $\begin{array}{l}\text { Darbe giri- } \\
\text { şimi bilgi- } \\
\text { lerine ilgi } \\
\text { düzeyi }\end{array}$ & $\mathrm{N}$ & $\%$ & $\begin{array}{l}\text { 'Darbe girişimi } \\
\text { hakkında } \\
\text { medya toplumu } \\
\text { yeteri kadar } \\
\text { bilgilendirmiş- } \\
\text { tir' önermesine } \\
\text { katılım düzeyi }\end{array}$ & $\mathrm{N}$ & $\%$ & $\begin{array}{l}\text { 'Darbenin önlen- } \\
\text { mesinde medya- } \\
\text { nın önemli bir } \\
\text { rolü olmuştur' } \\
\text { önermesine katı- } \\
\text { lım düzeyi }\end{array}$ & $\mathrm{N}$ & $\%$ \\
\hline $\begin{array}{l}\text { Çok yük- } \\
\text { sek }\end{array}$ & 165 & 37,6 & $\begin{array}{l}\text { Tamamen katı- } \\
\text { liyorum }\end{array}$ & 51 & 11,6 & $\begin{array}{l}\text { Tamamen katilı- } \\
\text { yorum }\end{array}$ & 183 & 41,7 \\
\hline Yüksek & 156 & 35,5 & $\begin{array}{l}\text { Birçok yönden } \\
\text { katılıyorum }\end{array}$ & 145 & 33 & $\begin{array}{l}\text { Birçok yönden } \\
\text { katılıyorum }\end{array}$ & 141 & 32,1 \\
\hline Orta & 80 & 18,2 & $\begin{array}{l}\text { Ne katiliyorum } \\
\text { ne katılmiyo- } \\
\text { rum }\end{array}$ & 84 & 19,1 & $\begin{array}{l}\text { Ne katıliyorum } \\
\text { ne katılmıyorum }\end{array}$ & 45 & 10,3 \\
\hline Düşük & 32 & 7,3 & $\begin{array}{l}\text { Kismen katıl1- } \\
\text { yorum }\end{array}$ & 104 & 23,7 & $\begin{array}{l}\text { Kismen katıliyo- } \\
\text { rum }\end{array}$ & 45 & 10,3 \\
\hline Hiç & 6 & 1,4 & $\begin{array}{l}\text { Hiç katılmıyo- } \\
\text { rum }\end{array}$ & 55 & 12,5 & Hiç katılmıyorum & 25 & 5,7 \\
\hline Toplam & 439 & 100 & Toplam & 439 & 100 & Toplam & 439 & 100 \\
\hline
\end{tabular}


Tablo 8' de 15 Temmuz 2016 darbe girişimine ilişkin veriler yer almaktadır. Anket çalışmasında üniversiteli gençlerin darbe girişimi bilgilerine ilgi gösterme düzeyleri sorgulanmıştır. Katılımcıların en fazla 'çok yüksek ilgi gösteriyorum' (165 kişi ve yüzde 37,6) ve 'yüksek ilgi gösteriyorum' (156 kişi ve yüzde 35,5) seçeneklerini işaretledikleri görülmüştür. Buradan hareketle Türkiye'de 15 Temmuz 2016 tarihinde gerçekleşen darbe girişimine ilişkin bilgilere üniversite öğrencilerinin yüksek oranda (yüzde 73,1) ilgi gösterdikleri belirtilmelidir. H1'de beklenildiği gibi üniversiteli gençlerin siyasal gündem konularını yakından takip ettikleri ortaya çıktığ gibi, H 7'de öne sürüldügü gibi siyasal gündeme ilişkin kriz durumunda üniversiteli gençlerin medyadan ve sosyal çevrelerinden gelen enformasyona aktif şekilde ilgi gösterdiği bulgulanmıştır.

Anket çalışmasında önemli siyasal gündem konularına ilişkin medyanın gençleri ne kadar bilgilendirdiği konusu da araştırılmak istenmiştir. Bu amaçla katılımcılara örnek olay olarak seçilen 15 Temmuz darbe girişimi karşısında medyanın kendilerini yeteri kadar bilgilendirdiği önermesi hakkındaki düşünceleri sorulmuştur. Katılımcılar bu önermeye en çok 'birçok yönden katılıyorum' (145 katılımcı ve \% 33 oranıla) cevabını vererek, medyanın yeteri kadar bilgi sağlamadığını düşündüklerini ifade etmişlerdir. Bu durumu ikinci ve üçüncü sırada 'kısmen katılıyorum', 'ne katılıyorum ne katılmıyorum' seçeneklerini işaretleyerek pekiştirmişlerdir. 15 Temmuz darbe girişimi sırasında kamuoyunun girişime ilişkin bilgilendirilmesinde bilhassa özel sektöre ait televizyonlar siyasi karar alma pozisyonundaki kişilerle (ki kamuoyu ile iletişim kurmak için resmi kaynaklardan mahrumdular) gerçekleştirdikleri canlı bağlantılarla önemli bir rol oynamıştır. Bu açıdan darbenin önlenmesinde medyanın önemli bir rolü olduğu önermesine katılıp katılmadıkları öğrencilere sorulmuştur. Bu önermeye en fazla 183 katılımcı (\% 41,7) 'tamamen katılıyorum' seçeneğini işaretlemiş, bunu 141 katılımcı (\% 32,1) ile ‘birçok yönden katılıyorum' seçeneği izlemiştir. Üniversite öğrencilerinin büyük bir oranda medyanın darbe girişiminin önlenmesinde önemli bir rolü olduğu fikrine katıldıkları ortaya çıkmıştır. H 8' de öne sürülen varsayım kısmen doğrulanmıştır. Şöyle ki, darbe girişimine ilişkin öğrenciler medyanın kamuoyunu yeteri kadar bilgilendirdiğini düşünmeseler de darbe girişiminin etkisiz kalmasında medyanın önemli rol oynadığını kabul etmişlerdir. 
Anket çalışmasının son sorusunda ise katılımcılardan '15 Temmuz Darbe Girişimi ve Medya' denildiği zaman akıllarına ilk gelen şeyin ne olduğunu bir ya da iki kelime ile ifade etmeleri istenilmiştir. Bu soru ile katılımcların medya ve darbe girişimi olayını nasıl ilişkilendirdiklerine dair zihinlerindeki resimler bulgulanmak istenmiştir. Verilen cevapların uzunluğuna göre kullanılan kelime ya da kavramlar cevaplar içerisinden çıkarılarak kategorize edilmiştir.

Tablo 9'a göre sırası ile gidilecek olursa katılımcıların önemli bir kısmının iletişim araçlarının örnek olaydaki rolüne ilişkin bir takım kavramlar kullandıkları görülmüştür. İletişim araçları kategorisine ilişkin en çok kullanılan kavramlar televizyon (20 katılımc1), TRT (17 katılımc1) ve CNN Türk (14 katılımcı) olmuştur. Bu kategoride TRT Sunucusu (12 katılımcı) ve Tijen Karaş (11 katılımcı) tanımlama ve isminin en çok kullanılan bir diğer tanımlama türü olduğunu söylemek gerekir. Ankete katılan üniversite öğrencilerinin darbe girişimi gecesinin medya aktörlerine ilişkin hafızalarında önemli kavramlar oluştuğu söylenebilir. Girişim gecesi TRT televizyonunun Ankara stüdyolarının darbeciler tarafından ele geçirilerek, darbe bildirisinin sunucu Tijen Karaş'a okutturulması katılımcıların zihnindeki en önemli resim olarak ortaya çıkmıştır. CNN televizyonunda Cumhurbaşkanı Erdoğan'ın canlı bağlantı ile halkı direnmeye çağırması da medyanın rolüne ilişkin katılımcıların zihninde doğan ikinci en önemli resim olmuştur.

Açık uçlu soruya verilen cevapların bir diğer kısmı ise 'darbe girişimi sırasında medya içeriği ve işlevine ilişkin değerlendirmeler' kategorisi içine sokulmuştur. 'Medya bilgilendirmesi' (17 katılımcl) ve 'medyanın gücü' (7 katılımc1) ile 'taraflı medya' (7 katılımc1), 'abartı' (6 katılımc1) en çok kullanılan ifadeler olmuştur. Bu kategori içerisinde darbe girişimi sirasında katılımcıların medyanın önemli bir işlev gördüğüne dair düşünceler beslediklerini ifade etmek gerekir. Bunun yanında yapılan haberleri iç siyasal konjonktür açısından değerlendirip, 'abartı' ifadesini kullanan katılımclar da olmuştur.

Darbe girişimi ve medyanın rolüne ilişkin verilen cevapların içerisinden oluşturulan bir diğer kategori de 'toplumsal ve siyasal kavramlar' kategorisidir. Bu kategoride 'halk' (15 katılımc1), 'sokağa çağrı' (11 katılımcı), 'toplumsal birlik' (10 katılımcı) ve 'vatan' (10 katılımcı) en çok kullanılan kavram ve ifadeler olmuştur. 
'Askeri ve siyasi aktörlere ilişkin kavramlar' kategorisi içerisinde en çok kullanılan isim ve kavramlar 'Cumhurbaşkanı'-'Tayyip Erdoğan' (sırasıyla 17-9 katılımcı), 'darbe' (17 katılımcı) ve 'FETÖ' (15 katılımcı) olmuştur.

Tablo 9. Katılımcıların açık uçlu soruya verdikleri cevaplardan oluşturulan kategoriler ve kullanım sıkliklar

\begin{tabular}{|c|c|c|c|c|c|}
\hline $\begin{array}{l}\text { İletişim araçla- } \\
\text { rına ilişkin kav- } \\
\text { ramlar }\end{array}$ & Frk. & $\begin{array}{l}\text { Medya içeriği ve } \\
\text { işlevine ilişkin } \\
\text { kavram ve değer- } \\
\text { lendirmeler }\end{array}$ & Frk. & $\begin{array}{l}\text { Toplumsal ve siya- } \\
\text { sal kavramlar }\end{array}$ & Frk. \\
\hline Televizyon & 20 & Abart1 & 6 & Halk & 15 \\
\hline CNN Türk & 14 & $\begin{array}{l}\text { Medyanın bilgi- } \\
\text { lendirmesi }\end{array}$ & 17 & Vatan & 10 \\
\hline TRT Sunucusu & 12 & Haber & 9 & Toplumsal birlik & 10 \\
\hline Tijen Karaş & 11 & Taraflı medya & 7 & Halkı örgütlemek & 3 \\
\hline Canlı Yayın & 5 & İletişimin önemi & 4 & Milli direniş & 4 \\
\hline Hande Firat & 2 & Haberdar olmak & 3 & Türklük & 4 \\
\hline 3 G Bağlantısı & 7 & Tarafsızlık ilkesi & 3 & Şehit & 5 \\
\hline TRT & 17 & Medyanın gücü & 7 & İç karışıklık & 3 \\
\hline \multirow[t]{6}{*}{ A Haber } & 8 & Yanlış bilgi & 2 & Birlik ve beraberlik & 5 \\
\hline & & Medya & 3 & Devlet bütünlüğü & 2 \\
\hline & & & & Kurtuluş mücadelesi & 2 \\
\hline & & & & Sokağa çağrı & 11 \\
\hline & & & & Millet & 3 \\
\hline & & & & Sokak nöbetleri & 4 \\
\hline $\begin{array}{l}\text { Askeri ve Siyasi } \\
\text { Aktörlere iliş- } \\
\text { kin kavramlar }\end{array}$ & Frk. & $\begin{array}{l}\text { Kişisel duygu ve } \\
\text { değerlendirmeler }\end{array}$ & Frk. & Sosyal Medya & Frk. \\
\hline FETÖ & 15 & Korku & 8 & Facebook & 4 \\
\hline Darbe & 17 & Tiyatro & 2 & Face Time & 12 \\
\hline Tank & 7 & Danışıklı dövüş & 2 & & \\
\hline Darbe Bildirisi & 5 & Endişe & 3 & $\begin{array}{l}\text { Sembolik Kavram- } \\
\text { lar }\end{array}$ & Frk. \\
\hline S1kıyönetim & 2 & Gülmek & 2 & Boğaziçi Köprüsü & 4 \\
\hline Cumhurbaşkanı & 17 & Tehlike & 2 & & \\
\hline \multirow[t]{2}{*}{ Tayyip Erdoğan } & 9 & İhanet & 4 & & \\
\hline & & Kaos & 2 & & \\
\hline
\end{tabular}

Bu kategori içerisine konulan cevaplarda kullanılan isim ve kavramlardan da anlaşılacağı üzere darbe girişimi ve medya ilişkisini katılımcıların bir kısmının siyasi ve askeri kavramlar ile tanımlama yoluna gitmiştir. Aynı açık uçlu soruya katılımcıların bir kısmının kişisel duygu ve değerlendir- 
melerini yansıtarak cevap verdiği de saptanmıştır. Örneğin 'korku' (8 katılımc1), 'ihanet' (4 katılımc1) ve 'endişe' (3 katılımc1) en çok dile getirilen kişisel duygu ve değerlendirme ifadeleri olmuştur.

Son olarak ayn soruya verilen cevaplardan 'Sosyal medya' kategorisi ile 'sembolik kavramlar' kategorileri oluşturulmuştur. Darbe girişimi s1rasında Cumhurbaşkanının bir telefon markasına özgü videolu görüşme programı olan 'Face time' (12 katılımc1) üzerinden televizyonların canlı yayınına bağlanması katılımcıların darbe girişimi ve medya ilişkisini ifade ederken en çok akıllarında kalanlardan birisi olmuştur. 'Boğaziçi köprüsü' ise en çok kullanılan sembolik kavram olmuştur. Çalışma kapsamında katılımcılara sorulan açık uçlu soru 15 Temmuz darbe girişimi olayı ve medya ilişkisinin katılımcıların zihninde nasıl bir resim oluşturduğunu ortaya koymak için hazırlanmıştır. Sonuç olarak katılımcıların darbe girişimi sırasında medyanın oynadığı rolü enformasyon kaynağı olarak çokça önemsedikleri ve bu enformasyon kaynağından gelen resimler ile de darbe girişimine ilişkin bilişsel ve görsel hafızalarını oluşturdukları saptanmiştır.

\section{Sonuç ve Tartışma}

Yapılan çalışma üniversite gençlerinin siyasal gündemlerinin kaynaklarını ve medya kullanım alışkanlıklarını ortaya çıkarma girişimidir. Özellikle siyasal kriz durumlarında kişisel gündemlerini nasıl ve ne ölçüde oluşturdukları bulgulanmak istenmiştir. Tahmin edildiği gibi değişen enformasyon teknolojilerinin de etkisiyle üniversiteli gençlerin enformasyon sağlama kaynaklarında da değişimler ve çeşitlenmeler olmuştur. Günümüzde genç nüfus rutin siyasal gündemlerini oluşturmak için geleneksel medya organlarına daha az ilgi göstermekle birlikte bunun için sosyal medya ve internet gazetelerini daha fazla kullanmaktadır. Bu durumu sadece teknolojik gelişme ile açıklamak yeterli değildir. Değişen yaşam tarzlarından değişen aile yapılarına ve hızlı tüketim kültürünün doğurduğu kolaycılığa kadar birçok sosyolojik ve psikolojik faktörü bu değişeme kaynak olarak göstermek mümkündür.

Siyasal gündem konularına katılımcıların yüksek oranda ilgi gösterdikleri bu çalışmadan çıkan önemli bir sonuçtur. Katılımcılar gündemden haberdar olduklarını yüksek oranda belirtirlerken, seçilen örnek olay gibi 
kriz durumu olarak nitelendirilebilecek durumlarda bu ilginin daha da arttığını ifade etmek gerekir. Çalışmada katılımcıların yüksek oranda 15 Temmuz darbe girişimi olayından haberdar oldukları hatta kendilerini bu konu da önemli oranda bilgili saydıkları sonucuna ulaşılmıştır. Şüphesiz üniversiteli genç öğrencilerin siyasal gündem konularına ilişkin bilgilerinin düzeyi çeşitli açılardan ölçülebilir. Fakat bu türden bir çaba çalışmanın sınırlarını daha da genişletmiş olacaktı. Dolayısıyla yapılan çalışmada sadece katılımcıların kendilerini siyaset gündemi hakkında ne kadar bilgili saydıklarına bakılmıştır.

Katılımcıların siyasal gündem konularını en çok yeni medya araçları ve sosyal medyadan takip ettikleri de ortaya çımıştır. Bu durumun siyasal tutum ve davranış geliştirme noktasında geçerli olduğu söylenemez. Zira katılımcıların bir siyasal tutum geliştirmenizde üzerinizde en çok etkili olan faktör nedir sorusuna verdikleri cevaplara göre internete dayalı enformasyon kaynaklarının kendine daha alt sıralarda yer bulduğu görülmüştür. Gençlerin siyasal gündem konularını takip etmek için internet ve sosyal medyayı yüksek oranda kullanması gerçeğine rağmen iş siyasal tutum geliştirmeye gelince daha geleneksel enformasyon kaynaklarını ve birincil ilişki şekillerinin geçerli olduğu ortamları (arkadaş, aile grupları, sivil toplum örgütleri vb.) daha çok kullandıkları sonucuna ulaşılmıştır. Bu durumun ortaya çıkmasında sosyal medya veya web tabanlı haber ortamlarında bilginin değişken olmasının yanında yalan, yanlış veya yanıltıcı bilginin denetlenememesinin, en azından hukuki bir çerçeve içerisinde bertaraf edilemeyeceği düşüncesinin etkili olduğu sanılmaktadır.

Anket çalışmasında örnek siyasal olay olarak seçilen darbe girişiminde medyanın oynadığı rolü gençlerin nasıl yorumladığı da araştırılan bir başka konu olmuştur. Türkiye'nin daha önceki siyasal tecrübelerinde hatırlanacağı üzere devlet televizyon ve radyosuna el konularak siyasetçi ile kamunun iletişimini kesmek yani enformasyon akışını engellemek günümüz medya araçlarının çeşitliliği düşünüldüğünde artık yeterli olmamaktadır. Seçilen örnek olayda da bu durum gözlenmiştir. Çalışma kapsamında anket uygulamasına katılan gençler de Türkiye'deki medyanın darbe girişimine ilişkin enformasyonun sağlanmasında hayati bir rol oynadığı dolayısıyla darbenin önlenmesinde medyanın enformasyon akışını sağlayarak önemli bir görev gördüğü düşüncesini ortaya koymuşlardır. 
Bunun yanında medyanın darbe girişimi sonrasında toplumu bilgilendirmede yeteri kadar etkili olduğu düşüncesine üniversiteli gençlerin katılmadığı sonucu da ortaya çıkmıştır. Darbe girişimi olayının ilerleyen safhalarında bilgiler daha da billurlaşmış, medyadan gelen enformasyon daha da çeşitlenmiştir. Böylece darbe girişimine ilişkin muhalif bilgiler de yayılmaya başlamıştır. Buna Türkiye'nin içinde bulunduğu siyasal konjonktürün kutuplaştırıcı etkisi de katıldığında medyanın toplumu yeteri kadar bilgilendirmediği şeklindeki yargının nasıl oluştuğu daha anlaşılmiş olur.

Sosyal medya ve haber portalları günümüz eğitimli gençliğinin en önemli haber kaynağıdır. Geleneksel medya araçlarından haber takibi ve gündeme ilişkin bilgi sağlama noktasında düşüş yaşanmaktadır. Ankette sorulan sorularla da bu durum tespit edilebilmiştir. Katılımcılar sosyal medyayı ve haber portallarını önemli oranda kullandıklarını ama buralarda paylaşımda bulunmadıklarını ifade etmişlerdir. Bu da bir bakıma internet tabanlı uygulamalarda katılımc bir kullanımdan ziyade pasif alımlayıcı bir kullanımın olduğunu göstermektedir. 15 Temmuz darbe sürecinde de katılımclar büyük oranda sosyal medyadan herhangi bir paylaşımda bulunmadıklarını dile getirerek bu durumu teyit etmiştir. Sonuç olarak eğitimli gençlerin günümüzde siyasal gündem konularına ilişkin enformasyon kaynaklarının çeşitlendiğini, bu çeşitliliği özellikle internet tabanlı yeni iletişim teknolojilerinin arttırdığını, geleneksel kitle iletişim araçlarının kullanımımın gittikçe azaldığın fakat bu araçların siyasal tutum geliştirmede hala önemini koruduğunu söylemek gerekir. Bunun yanında siyasal kriz durumlarında üniversiteli gençlerin siyasal gündemi yakından takip ettiği ve değerlendirdiği bilgisi de çalışmanın önemli bir sonucu olarak ortaya çıkmıştır.

\section{KAYNAKÇA}

Alkan, H. (2016). 15 temmuz'u anlamak: Parametreler ve sonuçlar. Bilig, 79, s. 253-272.

Arklan, Ü., ve Karakoç, E., (2015). Medyanın genel ve siyasal gündeme ilişkin bilgi edinme aracı olarak kullanımı: Görgül bir araştırma. Selçuk Üniversitesi Türkiyat Araştırmaları Dergisi 1(33), 325-363. 
Atabek, N., (1998). Gündem belirleme yaklaşımı. İstanbul Üniversitesi İletişim Fakültesi Dergisi, 7, 155-174.

Balcı, Ş. ve Damlapınar, Z., Pınarbaşı, T., E., Astam, F., K., (2016). Siyasal bilgilenmede medyanın rolü ve etkinliği: Üniversite öğrencileri araştırmasi. The Journal of Academic Social Science Studies, 53, 111126.

Cohen, B. (1963). The press and foreign policy. Princeton, NJ: Princeton University Press.

Dearıng, J., W. ve Rogers, E., M. (1996). Agenda Setting. NY: Sage Publications.

Devran, Y. ve Özcan, Ö. F., (2016). 15 temmuz darbe girişimi: Gelenekselden yeniye medya araçlarının kullanımı. AJIT-e: Online Academic Journal of Information Technology, 7(25),71-92. DOI: 10.5824/13091581.2016.4.004.x

Huck, I. and Quirıng O., Brosius, H., B., (2009). Perceptual phenomena in the agenda setting process. International Journal of Public Opinion Research, 21(2), 139-164.

Kosıckı, G. M. (1993). Problems and opportunities in agenda-setting research. Journal of Communication 43 (2).

Küçükkurt, M. ve Hazar, Ç. M., Çetin, M., Topbaş, H., (2009). Kullanımlar ve doyumlar yaklaşımı perspektifinden üniversite öğrencilerinin medyaya bakışı. Selçuk İletişim, 6(1), 37-50.

Manheım, J., B. (1978). Model of agenda dynamics (İn) Communication Yearbook 10, Margaret Mclaughlin (Edt.), P.499-516, Newbury Park, Cal.:Sage.

McCombs, M., (1981). Political agenda, (In) Media Agenda Setting İn A Presidential Election: Issues, Images And Interest (Edt. Weaver D H, Graber D, Mccombs M, Eyal C.), Praeger, New York.

McCombs, M., (1997). Building consensus: The news media's agenda-setting roles, (In) Political Communication, 14:4, Pp. 433-443, Do1: 10.1080/105846097199236.

McCombs, M., (2005). A look at agenda-setting: Past, present and future. Journalism Studies, 6(4), 543-557, Do1: 10.1080/14616700500250438

McQuail, D., ve Windahl, S.,, (1997). Kitle iletişim modelleri, (Çev.: Konca Yumlu), Ankara: İmge Kitabevi Yayınları. 
Melek, G., Toker, H., (2017). Şiddet, demokrasi ve terör bağlamında ana akım medyanın analizi: 15 temmuz darbe girişimi. Erciyes İletişim Dergisi "Akademia", 5(1), 222-234.

Rogers, E., M., and Dearıng, J., W., (2011). Agenda setting research: Where has it been? where is it going, (In) Communication Yearbook 11, J. A Anderson (Edt.), P. 555-594, Newbury Park: Sage.

Severın, W., J. Tankaard, J., W., (1994). İletişim kuramları: Kökenleri, yöntemleri ve kitle iletişim araçlarında kullanımları, (Çev.: Ali Atıf Bir, Serdar Seven), 1. Bask1, Eskişehir: Kibele Sanat Merkezi.

Shaw, D., L., and Mc Combs, M., E., (1997). The emergence of American political issues: The agenda setting functions of the press. St.Paul: West Publication Company.

Toruk, İ., (2008). Üniversite gençliğinin medya kullanım alışkanlıkları üzerine bir analiz. Selçuk Üniversitesi Sosyal Bilimler Dergisi, 19, 475488.

Türk Dil Kurumu, (1998). Türkçe sözlük. Ankara: Türk Dil Kurumu Yayınları.

Walgrave, S., and Soroka, S., Nuytemans, M., (2008). The mass media's political agenda-setting power a longitudinal analysis of media, parliament, and government in Belgium (1993 to 2000). Comparative Political Studies, 41(6), 814-836.

Yüksel, E. (2001). Medyanın gündem belirleme gücü.Konya: Çizgi Kitabevi Yayınları.

\section{Kaynakça Bilgisi / Citation Information}

Bayram, Y. (2017). Gençlerin siyaset gündemi konularına yaklaşımı ve medya kullanım alışkanlıklarının belirlenmesi: 15 temmuz darbe girişimi örnek olayı. OPUS - Uluslararası Toplum Araştırmaları Dergisi, 7(13), 887-911. 